\title{
TECCIENCIA
}

\section{Preliminary Analysis of Wind Power in 4 Colombian Cities, and Utilization Estimates with Urban Wind Turbines}

\section{Análisis preliminar del potencial eólico en 4 ciudades de Colombia y su aprovechamiento estimado a partir de aerogeneradores urbanos}

\author{
Fabian León-Vargas $^{1 *}$, Edwing Krejci ${ }^{1}$, Maira García-Jaramillo ${ }^{1}$ \\ ${ }^{\text {I} F a c u l t a d ~ d e ~ I n g e n i e r i ́ a ~ M e c a ́ n i c a, ~ U n i v e r s i d a d ~ A n t o n i o ~ N a r i n ̃ o, ~ B o g o t a ́, ~ C o l o m b i a . ~}$
}

\begin{abstract}
Wind power generates a significant percentage of electricity and is used by a great many countries, including the largest producers worldwide: China, the United States, Germany and Spain. Colombia has a wind energy potential of an estimated $21 \mathrm{GW}$ on its Atlantic coast alone, and yet in the nation as a whole only 19.5 MW are currently generated, coming from the Jeripachi wind farm in La Guajira. The utilization of this type of energy in other geographical locations is still undeveloped, sparking a need to evaluate its utility and profitability, such as in urban generation and consumption. In this paper we present the preliminary results of a study on the estimation of wind power in 4 cities, where weather stations have been set up at University Antonio Nariño installations. We measured variables such as wind speed, wind direction and environmental temperature .As a result, we statistically characterized wind speed in each location by fitting the data to a Weibull distribution. We also estimated the percentage of energy coverage that could be exploited in an average home using a domestic urban wind turbine. The study also presents a prefeasibility analysis of what could be expected from investment in self-generated electricity using such technology in the studied locations.
\end{abstract}

Keywords: Wind Potential Estimates, Wind Energy, Urban Generation.

\section{Resumen}

El potencial energético que se puede obtener a partir del viento, y del cual se logra un porcentaje importante de generación eléctrica, es utilizado por una gran cantidad de países alrededor del mundo, siendo China, EE. UU., Alemania y España los mayores productores respectivamente. En Colombia existe un potencial estimado de $21 \mathrm{GW}$ tan sólo en la costa atlántica y sin embargo en todo el territorio nacional sólo se cuenta con una generación de 19.5 MW provenientes del parque eólico de Jeripachi en la Guajira. El aprovechamiento de este tipo de energía en otras ubicaciones geográficas aún es incipiente, motivando la determinación de su utilidad y rentabilidad, por ejemplo, en implementaciones de esta tecnología para entornos de generación y consumo urbano. En este trabajo se presentan resultados preliminares de un estudio sobre la estimación del potencial eólico en 4 ciudades en las que se ha dispuesto una estación meteorológica, la cual se encuentra ubicada en instalaciones de la Universidad Antonio Nariño. Para el estudio se realizó la medición de variables como velocidad y dirección del viento y temperatura ambiente. Como resultado se caracterizó estadísticamente la velocidad del viento en cada ubicación a partir del ajuste de los datos a la distribución de probabilidad de Weibull y se realizó una estimación del porcentaje de cobertura energética que podría ser aprovechado en un hogar promedio a través de la implementación de un aerogenerador urbano doméstico. En este trabajo se presenta además un análisis de prefactibilidad que podría esperarse de la inversión en autogeneración de energía eléctrica a partir de esta clase de tecnología en las ubicaciones bajo estudio.

Palabras clave: Estimación del Potencial Eólico, Energía Eólica, Generación Urbana.

*Corresponding Author.

E-mail:fabianlen@uan.edu.co
How to cite: León-Vargas, F., Krejci, E., García-Jaramillo, M., Preliminary Analysis of Wind Power in 4 Colombian Cities, and Utilization Estimates with Urban Wind Turbines, TECCIENCIA, Vol. 12 No. 21, 53-59, 2016, DOI: http:/dx.doi.org/ 


\section{TECCIENCIA}

\section{Introduction}

In recent decades there has been a significant global effort at both the economic and technological level towards the efficient use of renewable energy sources in order to meet the growing energy demand without causing a negative impact on the environment.

The energy potential that can be obtained from wind - up to about $50 \%$ of electricity - is used by a great many countries around the world. China, the United States, Germany and Spain are the largest producers. In South America, according to a study by the REGSA project [1], Argentina and Brazil have the greatest wind energy potentials and have therefore done the greatest number of studies about it. Mexico is another country that has been the subject of several studies of wind energy potential in various states and cities [2] [3] [4] [5].

In Colombia, a few studies have been made estimating wind energy potential [6] [7], including a spatial distribution of wind estimation, known as a wind map, created in 2006 [8]. However, the geographical position of Colombia generates a wide variety of climates, and these variations can be significant in a particular region throughout the year [9]. These variations influence the estimation of wind for different areas in the same region, making it necessary to take direct measurements in the location of interest.

Moreover, the approval of Law 1715 of 2014, which concerns the regulation of the integration of renewable energy into the national grid, has revealed a renewed interest and commitment from the Colombian government to create mechanisms and incentives to promote electricity use and generation from unconventional sources [10]. Colombia has a wind energy potential of an estimated 21 GW on its Atlantic coast alone, and yet in the nation as a whole only $19.5 \mathrm{MW}$ is currently generated, coming from the Jeripachi wind farm in La Guajira. The use of this type of energy in other geographical locations is still undeveloped, sparking a need to evaluate its utility and profitability, such as in urban generation and consumption.

In this paper we present the preliminary results of a study on the estimation of the wind energy potential in four urban locations in Colombia: Manizales, Pasto, Cúcuta and Bogotá. In every location we have set up a weather station at University Antonio Nariño installations for this purpose. We statistically characterize wind speed in each location by fitting the data to a Weibull distribution. We also estimate the percentage of energy coverage that could be exploited for an average home using a domestic urban wind turbine. As an additional result we present a prefeasibility analysis that could be expected from investment in selfgenerated electricity using this kind of technology, in the studied locations.

\section{Materials and methods}

The cities chosen for the preliminary study are Bogota, Cucuta, Manizales and Pasto. Table 1 shows the geographical location of the weather stations and the measurement height in each case. It is important to note that wind speed data was obtained at 2-minute intervals during the months of July and August 2015.

Table 1 Location of weather stations and local height measurement.

\begin{tabular}{|c|c|c|c|}
\hline $\begin{array}{c}\text { Weather } \\
\text { Station }\end{array}$ & Length $(W)$ & Latitude $(N)$ & $\begin{array}{c}\text { Measureme } \\
\text { nt Height } \\
(\mathrm{m})\end{array}$ \\
\hline Bogota & $74^{\circ}: 6^{\prime}: 2,86^{\prime \prime}$ & $\begin{array}{c}4^{\circ}: 34^{\prime}: 46,37 \\
2^{\prime \prime}\end{array}$ & 20 \\
\hline Cucuta & $\begin{array}{c}72^{\circ}: 30^{\prime}: 7,836^{\prime} \\
7^{\circ}: 52^{\prime}: 52,24 \\
1^{\prime \prime}\end{array}$ & 12 \\
\hline $\begin{array}{c}\text { Manizal } \\
\text { es }\end{array}$ & $\begin{array}{c}75^{\circ}: 31^{\prime}: 45,71 \\
7^{\prime \prime}\end{array}$ & $\begin{array}{c}5^{\circ}: 2^{\prime}: 43,601^{\prime} \\
'\end{array}$ & 15 \\
\hline Pasto & $\begin{array}{c}77^{\circ}: 17^{\prime}: 24,03 \\
9^{\prime \prime}\end{array}$ & $\begin{array}{c}1^{\circ}: 12^{\prime}: 2,808^{\prime} \\
'\end{array}$ & 20 \\
\hline
\end{tabular}

\subsection{Estimation of wind energy potential}

Estimating the wind energy potential in each location was determined from wind speed data $(u)$ and adjustment to the density function of the Weibull distribution probability, in equation (1); where $k$ and $\lambda$ represent shape and scale parameters $(\mathrm{m} / \mathrm{s})$ respectively. These parameters are estimated using the least squares method with the help of the Matlab ${ }^{\circledR}$ software tool Distribution Fitting.

$$
p(u)=\frac{k}{\lambda}\left(\frac{u}{\lambda}\right)^{k-1} e^{-\left(\frac{u}{\lambda}\right)^{k}}
$$

The density of average power available, or wind potential $P_{e}$, is proportional to the air density $(\rho)$ and to the integral of the cube of the speeds, weighted by the density function $p(u)$, equation (2).

$$
P_{e}=\frac{1}{2} \rho \int_{0}^{\infty} u^{3} p(u) d u
$$

In order to determine a comparable wind energy potential between the different measurement locations, the $P_{e}$ calculation should take into account the variation of the characteristics of wind when height changes. In this study, we do not have a uniform height measurement for all 


\section{TECCIENCLA}

seasons and it is thus necessary to normalize the measures with a height reference. This process of normalization requires a roughness parameter $z_{0}$, in equation (3), which depends on the type of land [12].

Additionally, equations (4) to (6), based on the JustusMikjail formulas [13], help in estimating the value of the parameters of the Weibull distribution for any height reference lower than $100 \mathrm{~m}$ and with low roughness:

$$
\begin{aligned}
& \mu^{\prime}=\mu \frac{\ln \left(\frac{z^{\prime}}{z_{0}}\right)}{\ln \left(\frac{z}{z_{0}}\right)} \\
& k^{\prime}=k\left[\frac{1-0,088 \ln \left(\frac{z}{10}\right)}{1-0,088 \ln \left(\frac{z^{\prime}}{10}\right)}\right] \\
& \lambda^{\prime}=\lambda\left(\frac{z^{\prime}}{z}\right)^{\beta} \\
& \beta=\frac{0,37-0,088 \ln (\lambda)}{1-0,088 \ln \left(\frac{z}{10}\right)}
\end{aligned}
$$

Where $z^{\prime}$ is the height reference, $z$ is the measurement height, $\beta$ is a coefficient, and $\mu^{\prime}, k^{\prime}$ and $\lambda^{\prime}$ are the new values for average speed and the parameters of the Weibull distribution, respectively.

\subsection{Power and energy estimates}

In order to estimate the final average power $P_{m}$ obtained from a wind turbine, we use the Weibull method of probability density function $p(u)$ and the wind turbine power curve $W(u)$, in equation (7).

$$
P_{m}=\int_{0}^{\infty} p(u) W(u) d u
$$

Nonetheless, the estimate should be corrected for locations where the air density is different from the standard $(1.225$ $\mathrm{kg} / \mathrm{m}^{3}$ ) using the $k_{d}$ factor. See equation (8), where $T$ is temperature (in ${ }^{\circ} \mathrm{C}$ ) and $h$ is the height above sea level (m). Equation (9) is then used to calculate the real average power output $P_{m r}$ [13].

$k_{d}=\left(\frac{288}{T+273}\right) e^{-\frac{h}{8435}}$

$$
P_{m r}=k_{d} \int_{0}^{\infty} p(u) W(u) d u
$$

Finally, the generated energy depends on the real average power output $P_{m r}$, for a time $t$ (hours), in equation (10).

$E=t P_{m r}$

\subsection{Prefeasibility estimates}

To determine the cost per $\mathrm{kWh}$ produced from a wind generation project, we use equation (11) [14]. Where $C E$ is the cost of equipment, $C I$ is the cost of installation, $C M A$ is the annual maintenance cost, $V U$ is the lifetime in years and $P_{m r}$ is the real average power output of the wind turbine.

Cost per $k W h=\frac{C E+C I+(C M A * V U)}{365 * 24 * V U * P_{m r}}$

To determine the payback period for the wind generation project, or the time it takes to break even on the original investment, we use equation (12) [14]. Where $C_{r e f}$ is the cost per reference $\mathrm{kWh}$ for conventional generation.

Payback period $=\frac{C E+C I}{365 * 24 * P_{m r} * C_{r e f}-C M A}$

\section{Results and Discussion}

\subsection{Wind energy potential}

In Table 2 we present the average and the maximum average for the wind speeds obtained in each location. Table 3 shows the mean values of ambient temperature, the altitude above sea level and the respective air density for each location.

Table 2 Average and maximum average wind speed in each of the weather station locations.

\begin{tabular}{|c|c|c|}
\hline Weather Station & $\mu(\mathrm{m} / \mathrm{s})$ & $\mu_{-} \max (\mathrm{m} / \mathrm{s})$ \\
\hline Bogota & 2.36 & 3.85 \\
\hline Cucuta & 3.51 & 6.11 \\
\hline Manizales & 1.42 & 2.43 \\
\hline Pasto & 4.22 & 6.10 \\
\hline
\end{tabular}

Table 3 Temperature, atmospheric pressure and air density in each location.

\begin{tabular}{|c|c|c|c|}
\hline $\begin{array}{c}\text { Weather } \\
\text { Station }\end{array}$ & $\begin{array}{c}\text { Temperature } \\
\left({ }^{\circ} \mathrm{C}\right)\end{array}$ & $\begin{array}{c}\text { Height } \\
\text { above } \\
\text { sea level } \\
(\mathrm{m})\end{array}$ & $\begin{array}{c}\text { Air density } \\
\left(\mathrm{kg} / \mathrm{m}^{3}\right)\end{array}$ \\
\hline Bogota & 14.72 & 2580.2 & 0.903 \\
\hline Cucuta & 28.80 & 321.4 & 1.125 \\
\hline Manizales & 18.78 & 1940.3 & 0.961 \\
\hline Pasto & 13.22 & 2653.6 & 0.900 \\
\hline
\end{tabular}




\section{TECCIENCIA}

For this study we chose a reference height of 20 meters in order to make the results comparable between the different locations. Table 4 shows the terrain roughness values, the values of average wind speed and the Weibull scale and shape parameters at an altitude of 20 meters, obtained from equations (3) to (6).

Table 4 Terrain roughness for each location, average wind speed and Weibull parameters at an altitude of 20 meters.

\begin{tabular}{|c|c|c|c|c|}
\hline $\begin{array}{c}\text { Weather } \\
\text { Station }\end{array}$ & $\begin{array}{c}\text { Roughness } \\
\text { length }(\mathrm{m})\end{array}$ & $\begin{array}{c}\mu^{\prime} \\
(\mathrm{m} / \mathrm{s})\end{array}$ & $\begin{array}{c}\text { Shape } \\
\text { Factor } \\
k^{\prime}\end{array}$ & $\begin{array}{c}\text { Scale } \\
\text { Factor } \\
\lambda^{\prime}(\mathrm{m} / \mathrm{s})\end{array}$ \\
\hline Bogota & 0.4 & 2.36 & 1.48 & 2.61 \\
\hline Cucuta & 0.2 & 3.95 & 2.50 & 4.45 \\
\hline Manizales & 0.1 & 1.50 & 1.86 & 1.76 \\
\hline Pasto & 0.2 & 4.22 & 1.87 & 4.75 \\
\hline
\end{tabular}

Finally, Table 5 shows the values of wind power available in each location, taking into account the results of Table 4. This is calculated from equation (13), which corresponds to the discretization of equation (2), for speeds between 0 and $30 \mathrm{~m} / \mathrm{s}$ and a step $\Delta u=1(\mathrm{~m} / \mathrm{s})$

$P_{e}=\frac{1}{2} \rho \Delta u \sum_{n=0}^{30} n^{3} p(n)$

Table 5 Available wind power.

\begin{tabular}{|c|c|}
\hline Weather Station & Power Density $\left(\mathrm{W} / \mathrm{m}^{2}\right)$ \\
\hline Bogota & 16.41 \\
\hline Cucuta & 54.54 \\
\hline Manizales & 3.78 \\
\hline Pasto & 69.42 \\
\hline
\end{tabular}

\subsection{Urban power potential}

For this study we chose the Enair 70 domestic horizontal axis wind turbine: $4.1 \mathrm{~m}$ in diameter, $2 \mathrm{~m} / \mathrm{s}$ boot speed (cutin) and $3.5 \mathrm{~kW}$ rated power [15]. Figure 1 shows the power curves and the power coefficient of the wind turbine. Equation (14) is used to calculate the average power from tabulated values of the wind turbine power curve. This equation corresponds to the discretized version of equation (9), where $p(n)$ and $W(n)$ correspond to the Weibull density probability and the wind turbine power output, respectively, for speeds from 0 to $30 \mathrm{~m} / \mathrm{s}$ with a step $\Delta u=$ $1(\mathrm{~m} / \mathrm{s})$. The $k_{d}$ parameter is obtained from equation (9) and values from Table 3 .

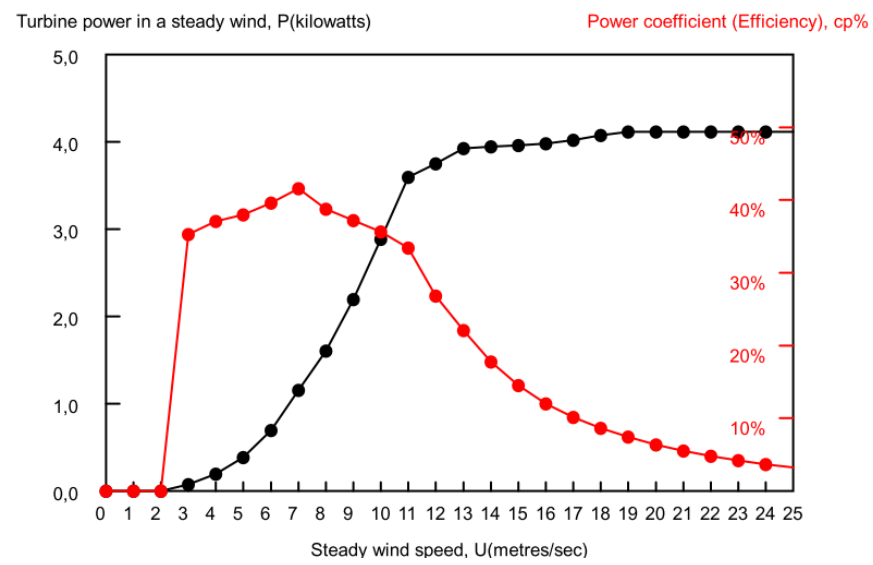

Figure 1 Power curve and power coefficient of a small wind turbine, the Enair 70.

$P_{m r}=k_{d} \Delta u \sum_{n=0}^{30} p(n) W(n)$

Table 6 shows the values of average power output, energy produced for July and August (assuming no additional losses on the disposal of wind potential), and the respective load factor.

Table 6 Average power output, energy produced in July and August, and load factor of the Enair 70 in each location.

\begin{tabular}{|c|c|c|c|}
\hline $\begin{array}{c}\text { Weather } \\
\text { Station }\end{array}$ & $\begin{array}{c}\text { Average } \\
\text { Power } \\
\text { Output }(\mathrm{kW})\end{array}$ & $\begin{array}{c}\text { Energy for } \\
\text { July and } \\
\text { August }(\mathrm{kWh})\end{array}$ & $\begin{array}{c}\text { Load } \\
\text { Factor } \\
(\%)\end{array}$ \\
\hline Bogota & 0.077 & 114.71 & 2.2 \\
\hline Cucuta & 0.275 & 409.74 & 7.8 \\
\hline $\begin{array}{c}\text { Manizal } \\
\text { es }\end{array}$ & 0.011 & 16.17 & 0.3 \\
\hline Pasto & 0.337 & 501.36 & 9.6 \\
\hline
\end{tabular}

Using the results in Table 6 and estimating a monthly energy consumption of $365 \mathrm{kWh}$ for an average Colombian household, Table 7 shows the percentage of energy coverage that the Enair 70 could satisfy at each location for the months of July shows and August.

\subsection{Small wind turbine prefeasibility project for urban environment}

The base costs for the analysis include total equipment cost (EC), installation cost (IC), and the annual maintenance cost (AMC). For this study there is an estimated IC and 
$\mathrm{AMC}$ of $10 \%$ and $1 \%$ of the $\mathrm{EC}$, respectively. Table 8 shows the estimated costs of equipment for a wind power generation project with the Enair 70. These costs include VAT (value added tax) of $21 \%$ [15].

Table 7 Energy coverage obtained by the Enair 70 for July and August.

\begin{tabular}{|l|c|}
\hline Location & $\begin{array}{l}\text { Average energy coverage } \\
(\%)\end{array}$ \\
\hline Bogotá & 15.7 \\
\hline Cúcuta & 56.1 \\
\hline Manizales & 2.2 \\
\hline Pasto & 68.7 \\
\hline
\end{tabular}

Table 8 Original costs for a wind power generation project using the Enair 70.

\begin{tabular}{|l|c|}
\hline Equipment & Cost $(\epsilon)$ \\
\hline Enair 70 & 8934 \\
\hline Inverter MP 3K-60A & 545 \\
\hline 6 Batteries 8OPZS & 1829 \\
\hline Total & 11308 \\
\hline
\end{tabular}

The Euro $(€)$ was chosen as the monetary unit for this analysis because of its global nature. We used a Colombian Peso to Euro exchange rate of 3000:1, obtained from the monthly average last year. However, due to the variable trend of this relationship, the results of this analysis may shift significantly over time. Table 9 shows the average cost per kWh of reference average $C_{r e f}$ over the last year for each location that is part of the study. This is shown in terms of "estrato," which is a Colombian system for classifying the socioeconomic level of a residential area, with 1 being the lowest and 6 being the highest. This study shows the costs in estrato 4 and estrato 5 areas, or middle class and upper middle class residences. The cost per $\mathrm{kWh}$ for estrato 6, the highest class, is the same as for estrato 5 for all locations.

Table 9 Cost per kWh of reference $C_{\text {ref }}$ for estratos 4 and 5 during the past year.

\begin{tabular}{|l|c|c|}
\hline City & $\begin{array}{l}C_{\text {ref }} \text { estrato 4 } \\
(\epsilon)\end{array}$ & $C_{\text {ref estrato 5 }(\epsilon)}$ \\
\hline Bogotá & 0.125 & 0.150 \\
\hline Cúcuta & 0.127 & 0.152 \\
\hline Manizales & 0.122 & 0.146 \\
\hline Pasto & 0.142 & 0.171 \\
\hline
\end{tabular}

In determining the payback period, only estratos 4 and 5 are included, since there cost per $\mathrm{kWh}$ is highest, which in theory could result in a more attractive power generation project.

Table 10 shows the cost per $\mathrm{kWh}$ obtained from equation (11), results from the wind generation project in each location. This calculation used a service life of 20 years.

Table 10 Cost per $\mathrm{kWh}$ of the wind power generation project.

\begin{tabular}{|l|c|}
\hline City & Cost per $k W h(\epsilon)$ \\
\hline Bogotá & 1.089 \\
\hline Cúcuta & 0.305 \\
\hline Manizales & 7.627 \\
\hline Pasto & 0.249 \\
\hline
\end{tabular}

Table 11 shows the payback period, obtained from equation (12), results of the wind generation project in each location and for estratos 4 and 5.

Table 11 Payback period for the wind generation project.

\begin{tabular}{|l|c|c|}
\hline City & $\begin{array}{l}\text { Payback period } \\
\text { for estrato 4 (in } \\
\text { years) }\end{array}$ & $\begin{array}{l}\text { Payback period } \\
\text { for estrato 5 (in } \\
\text { year) }\end{array}$ \\
\hline Bogotá & Never! & Never! \\
\hline Cúcuta & $>50$ & 49 \\
\hline Manizales & Never! & Never! \\
\hline Pasto & 40.5 & 31.7 \\
\hline
\end{tabular}

The price per $\mathrm{kWh}$ of the wind power project is noticeably not lower than the reference price in any of the cities. Similarly, no case pays back the initial investment within the service life of the turbine.

\subsection{Pre-feasibility of the effect of legal incentives}

The results of Tables 10 and 11 are based on the original price of the wind power project. However, there are legal incentives in Colombia that provide benefits for the implementation of such systems (Law 1715). Thus, in Tables 12 and 13 we can see the results of the cost per $\mathrm{kWh}$ 


\section{TECCIENCLA}

and payback period for the project applying the incentive of VAT exemption on the equipment.

Table 12 Cost per $\mathrm{kWh}$ for the wind power generation project without VAT.

\begin{tabular}{|l|c|}
\hline City & Cost per kWh $(\epsilon)$ \\
\hline Bogotá & 0.861 \\
\hline Cúcuta & 0.241 \\
\hline Manizales & 6.026 \\
\hline Pasto & 0.197 \\
\hline
\end{tabular}

Table 13 Payback period for the wind generation project without VAT.

\begin{tabular}{|l|c|c|}
\hline City & $\begin{array}{l}\text { Payback period } \\
\text { for estrato 4 (in } \\
\text { years) }\end{array}$ & $\begin{array}{l}\text { Payback period } \\
\text { for estrato 5 (in } \\
\text { years) }\end{array}$ \\
\hline Bogotá & Never & $>50$ \\
\hline Cúcuta & 45.4 & 35.4 \\
\hline Manizales & Never & Never \\
\hline Pasto & 29.7 & 23.6 \\
\hline
\end{tabular}

Applying the VAT exemption incentive is shown to proportionally reduce the cost per $\mathrm{kWh}$ by $21 \%$. However, the resulting cost is still higher than the reference value in all cases. A similar result occurs with the payback period, which has been reduced by approximately $27 \%$. However, in no case do we break even on the initial investment within the lifetime of the turbine.

As part of the discussion that results from these findings, note that the cities chosen are just a sample of the locations where it is of interest to study the possibilities of local wind power for energy self-sufficiency in the urban environment. A further and more complete analysis should include a greater number of Colombian cities.

The chosen wind turbine has both technical characteristics and prices comparable to the average of well-performing small wind turbines that can be used to analyze domestic wind utilization. However, other turbines, with both horizontal axis and vertical axis, could be used for a similar analysis, further considering performance and economic feasibility.

At the moment, legal incentives in Colombia have not yet been carried out, despite Law 1715 already taking effect. In this paper we nevertheless included a VAT exemption on the equipment as a legal incentive in order to determine its influence on project prefeasibility. A more precise estimate of the potential impact of Law 1715 should include all legal incentives. In any case, it is necessary to have measurement data for at least one year in order to obtain more accurate estimates of both the wind potential and the economic viability of a project of urban wind generation in each of the studied locations.

\section{Conclusions}

We performed a preliminary wind potential analysis in 4 urban locations in Colombia, each with different characteristics in parameters such as temperature, atmospheric pressure and terrain roughness. From these preliminary results we performed a prefeasibility analysis for a proposed urban wind generation project, considering the case with and without legal incentives. The results show that investment in a project of this kind is not economically viable in any studied location, even with legal incentives that promote its development. Moreover, the results indicate that no location is able to cover $100 \%$ of the energy needs of an average Colombian household. However, due to the preliminary nature of this study, more definitive results may differ.

\section{Acknowledgements}

This work was funded by the University Antonio Nariño, through Project No. 20141110.

\section{References}

[1] REGSA - Promoting Renewable Electricity Generation in South America. Generación de electricidad a partir de energías renovables en América del Sur. Análisis comparativo de las condiciones institucionales y técnicas relevantes para la integración de las energías renovables en América del Sur. 2014

[2] Hernández-Escobedo Q, Espinosa-Arenal F, Saldaña-Flores R, Rivera-Blanco C. Evaluación del potencial eólico para la generación de energía eléctrica en el estado de Veracruz, México, DYNA 2011; 79(171).

[3] Suarez Camargo G, Garcia Barriga N. Preliminary identification study of the wind resource at the State of Michoacán. 2014 IEEE International Autumn Meeting on Power, Electronics and Computing (ROPEC) 2014, p 1-7.

[4] Larios Vázquez A. Desarrollo y prospectivas de energía renovable en México, Economía Informa 2015; 390:132-135. 
[5] Kawas N, Mejía Escobar EJ, Gómez Canales GJ. Determinación del potencial de generación de energía renovable en la UNA. Revista Ciencia y Tecnología 2013; 13:96-109.

[6] Avellaneda Cusaría A, Varila Quiroga J. Estudio del potencial de generación de energía eólica en la zona del páramo de Chontales, municipios de Paipa y Sotaquirá, departamento de Boyacá a 3534 m.s.n.m. AVANCES Investigación en Ingeniería 2013; 10(2):18-26.

[7] Ulianov López Y. Análisis de recurso solar y eólico en Colombia. Caso Valle del Cauca. El Hombre y la Máquina 2011; 37:34-42.

[8] Unidad de Planeamiento Minero Energético (UPME). Instituto de Hidrología, Meteorología y Estudios Ambientales (IDEAM). Atlas de viento y energía eólica en Colombia. Bogotá 2006.

[9] Castillo Y, Castrillón Gutiérrez M, Vanegas-Chamorro M, Valencia G, Villicaña E. Rol de las Fuentes No Convencionales de Energía en el sector eléctrico colombiano. Prospectiva 2015; 13(1):39-51.

[10] Ortiz D, Sabogal J, Hurtado E. Una revisión a la reglamentación e incentivos de las energías renovables en colombia. Revista Facultad de Ciencias Económicas, Investigación y Reflexión 2015; 20(2):5567.

[11]EPM. Energías Alternativas: Jepírachi una experiencia con la comunidad indígena Wayuu en la Guajira colombiana. Revista EPM: Jepírachi 2010.

[12] Danish Wind Industry Association (DWIA), www.windpower.org

[13]Villarrubia López M. Ingeniería de la Energía Eólica, Nuevas Energías. Marcombo 2011.

[14] Wind Power Program, http://www.wind-power-program.com

[15] Enair company, http://www.enair.es 